medical staff need to have a grasp of the drugs used and their pharmacology. ${ }^{17}$ Resuscitation and immediate management in the accident and emergency department can be critically important in preventing complications and ensuring a successful outcome. An understanding of the toxic mechanisms involved can enable one to employ a more rational approach to the clinical management of the acutely ill drug abuser.

JOHN A HENRY

Medical Toxicology Unit, Guy's Hospital, London SE1 9RT

1 Hoffman RS, Smilkstein MJ, Goldfrank LR. Whole bowel irrigation and the cocaine body-packer: a new approach to a common problem. $\mathrm{Am} \mathcal{F} \mathrm{Emerg}$ Med 1990;8:523-7.

2 Pollack CV, Biggers DW, Carlton SB, et al. Two crack cocaine body stuffers. Ann Emerg Med 1992;21:1370-80.

3 Lancaster MJR, Legg PK, Lowe M, Davidson SM, Ellis BW. Surgical aspects of international drug smuggling. BMf 1988;296:1035-7.

4 Osterwalder J. Naloxone - for intravenous heroin and heroin mixtures harmless or hazardous? A prospective clinical study. Clin Toxical 1996:34:409-16.

5 Gueye PN, Hoffman JR, Taboulet P. Vicaut E, Baud FJ. Empiric use of flumazenil in comatose patients: limited applicability of criteria to define low risk. Ann Emerg Med 1996;27:730-5.
6 Escobedo LG, Ruttenber AJ, Anda RF, Sweeney PA. Coronary artery disease, left ventricular hypertrophy, and the risk of cocaine overdose death. Coronary Artery Dis 1992;3:853-7.

7 Goldfrank LR, Hoffman RS. The cardiovascular effects of cocaine. Ann Emerg Med 1991;20:165-75.

8 Peroutka SJ. Incidence of recreational use of 3,4 methylenedioxymethamphetamine (MDMA, Ecstasy) on an undergradumethylenedioxymethamphetamine (MDMA

Randall T. Ecstasy-fueled 'rave' parties become dances of death for English youths. $\mathcal{F} A M A$ 1992;268:1505-6.

10 Henry JA, Jeffreys KJ, Dawling S. Toxicity and deaths from 3,4methylenedioxymeth-amphetamine ("ecstasy"). Lancet 1992;340:384-7. 1 O'Connor B. Hazards associated with the recreational drug 'ecstasy'. $B$ fHosp Med 1994;52:507-14.

12 Maxwell DL, Polkey MI, Henry JA. Hyponatraemia and catatonic stupor after taking "ecstasy". BMF 1993;307:1399.

13 Matthai SM, Davidson DC, Sills JA, Alexadrou D. Cerebral oedema after ingestion of MDMA ("ecstasy") and unrestricted intake of water. $B M^{f}$ 1996;312:1359.

14 Holden R. Jackson MA. Near-fatal hyponatraemia coma due to vasopressin oversecretion after "ecstasy" (3,4-MDMA). Lancet 1996; 347: 1052.

15 Ellis AJ, Wendon JA, Portmann B, Williams R. Acute liver damage and ecstasy ingestion. Gut 1996;38:454-8.

16 McGuire PK, Cope H, Fahy TA. Diversity of psychopharmacology associated with use of 3,4-methylenedioxymethamphetamine ("Ecstasy"). $B r \mathscr{F}$ Psychiatry 1994;165:391-5.

17 Brown ERS, Jarvie DR, Simpson D. Use of drugs at "raves". Scot Med $\mathcal{f}$ 1995;40:168-71.

\title{
Management issues in accident and emergency medicine
}

Management is a part of the job of any consultant in the NHS, but for accident and emergency (A\&E) consultants it is a crucial, often dominant, and generally stressful part of their work. It is also extremely time consuming. A leading consultant in the early eighties publicly stated that management issues occupied $80 \%$ of his working week, and although the situation may have changed somewhat with the advent of multiconsultant departments, it remains as important as ever to deal with these issues as effectively and as efficiently as possible so that there is time for the consultant to maintain a visible presence in the department, teach the junior staff, and conduct research and audit.

To the uninitiated, the term "management" conjures up an unappealing vista of boring committee meetings, intrusive administrators, and accountants demanding improved performance and diminishing expenditure. As with most caricatures, there are elements of truth within this view, but management is really much more than this. It is, in the words of John Harvey Jones, about "making things happen", and this entails learning how to deal effectively with people. Within the A\&E department, this involves forming, leading, and nurturing an effective clinical team. Junior medical staff need to be selected, trained, and assessed, and positive and effective relationships with our nursing colleagues and others working in the department need to be forged and maintained so that a "them and us" situation does not develop.

Relationships with those outside the department are equally important. The way duty teams behave in the department and the support they provide to our junior staff need continuous examination, sometimes involving difficult negotiations with consultant colleagues. Local general practitioners, often neglected in the past by $A \& E$ staff, quite naturally expect more and better information about their patients' attendances at A\&E departments. Many newsworthy events tend to occur in $A \& E$ departments and local news media are likely to pay a periodic interest in activities there and request interviews with staff involved.

$A \& E$ is surrounded by a morass of legal issues which may prove particularly daunting for the newly appointed consultant. Relationships with the police and the nature and quantity of patient information that may be released to them are frequent problems in $A \& E$, and a variety of legal and ethical dilemmas regularly confronts the $A \& E$ consultant. Handling claims of clinical negligence and the avoidance of these by clinical risk management are also important and time consuming parts of the consultant's duties.

The A\&E clinical team will not function effectively unless it is provided with the facilities to do so. The fabric and maintenance of the department must be attended to, as must the updating of equipment and the purchasing of new equipment for changing clinical needs. Provision of a safe working environment is a particular issue in most $A \& E$ departments as the incidence of verbal and physical assault on staff increases.

Given the enormous variety and significance of issues such as these, it is scarcely surprising that newly appointed $A \& E$ consultants find management the most challenging part of their work. Trainees rightly expect that they should receive proper training in this important area of their future activities, and this demand led to my organisation of the first management course specifically for $A \& E$ trainees in 1988. Since then, various other initiatives have begun, and the demand for the original course (run on a two yearly basis) has grown to the point where it appears that it will need to be run annually. The importance of management in $A \& E$ has recently been recognised by the Faculty of Accident and Emergency Medicine, which includes management problems in its exit examinations.

Training people in management is complex; there are frequently no "right" or "wrong" answers, and the correct methods of dealing with difficult situations are generally derived from shared experience rather than from textbooks or direct instruction. The series on "Management issues in accident and emergency" that starts with this issue of the Journal is thus warmly to be welcomed. Not only will it serve to reinforce management training already in progress, but it should also provide a forum for the experience of established consultants to be shared. It is to be hoped that the opinions expressed in the series generate some lively correspondence.

STEPHEN A D MILES Accident $\mathcal{E}$ Emergency Consultant Royal Hospitals NHS Trust, London E1 